Published in final edited form as:

Acta Physiol (Oxf). 2021 January ; 231(1): e13487. doi:10.1111/apha.13487.

\title{
Immunity and Hypertension
}

RM Zhang ${ }^{1, \dagger}$, KP McNerney $^{2, \dagger}$, AE Riek ${ }^{1, \dagger}$, C Bernal-Mizrachi ${ }^{1,3,4,{ }^{*}}$

${ }^{1}$ Department of Medicine, Division of Endocrinology, Metabolism, and Lipid Research, Washington University School of Medicine, St. Louis, MO

${ }^{2}$ Department of Pediatrics, Washington University School of Medicine, St. Louis, MO

${ }^{3}$ Department of Cell Biology and Physiology, Washington University School of Medicine, St. Louis, $\mathrm{MO}$

${ }^{4}$ Department of Medicine, VA Medical Center, St. Louis, MO

\section{Abstract}

Hypertension is the primary cause of cardiovascular mortality. Despite multiple existing treatments, only half of those with the disease achieve adequate control. Therefore, understanding the mechanisms causing hypertension is essential for the development of novel therapies. Many studies demonstrate that immune cell infiltration of the vessel wall, kidney, and central nervous system, as well as their counterparts of oxidative stress, the renal renin-angiotensin system (RAS), and sympathetic tone play a critical role in the development of hypertension. Genetically modified mice lacking components of innate and/or adaptive immunity confirm the importance of chronic inflammation in hypertension and its complications. Depletion of immune cells improves endothelial function, decreases oxidative stress, reduces vascular tone, and prevents renal interstitial infiltrates, sodium retention, and kidney damage. Moreover, the ablation of microglia or central nervous system perivascular macrophages reduces RAS-induced inflammation and prevents sympathetic nervous system activation and hypertension. Therefore, understanding immune cell functioning and their interactions with tissues that regulate hypertensive responses may be the future of novel antihypertensive therapies.

\section{Keywords}

Immunity; hypertension; macrophages; lymphocytes; renin-angiotensin system; reactive oxygen species

\section{Introduction}

Hypertension is the most common chronic disease and the major cause of heart failure, stroke, chronic kidney disease, and mortality in the Western world. About 75 million people

\footnotetext{
"Correspondence to: Carlos Bernal-Mizrachi, 660 S. Euclid Ave., Campus Box 8127, St. Louis, MO 63110, cbernal@wustl.edu.

$\dagger$ Authors contributed equally

Conflict of interests: None.

Data Sharing: No Applicable.
} 
have high blood pressure, but only about half of these people achieve control. ${ }^{1}$ Evidence for immune mechanisms contributing to the pathogenesis of hypertension was described a quarter of a century ago. In a deoxycorticosterone acetate (DOCA)-salt model of saltinduced hypertension, investigators found an intact thymus was required for hypertension. ${ }^{2}$ Subsequently, multiple observations in various animal models of hypertension confirmed immune suppression ameliorates or prevents the development of hypertension. ${ }^{3-12}$ In humans, vascular and renal macrophage infiltration correlates with the severity of hypertension in both Caucasian and African Americans. ${ }^{13}$ Over the last two decades, several studies have proposed an independent correlation between systemic inflammation and increased risk of hypertension and cardiovascular disease. ${ }^{14-18}$ Therefore, increasing our understanding of the mechanisms causing hypertension is essential for the development of novel therapies.

\section{Inflammation and Hypertension}

Innate immune responses are rapid and not unique to a specific pathogen. They rely on phagocytic cells that recognize specific pathogen-associated molecular patterns (PAMPs) common to many pathogens but are absent from the host and host-derived endogenous molecules that arise due to cell death and injury [damage-associated molecule patterns (DAMPs)]. ${ }^{19,20}$ These pathogen-associated molecules activate inflammatory responses and phagocytosis by neutrophils and macrophages. Both cell types display a variety of cellsurface pattern recognition receptors (PRR). These include Toll-like receptors (TLRs), nucleotide-binding oligomerization domain receptors (NOD-like receptors), leucine-rich repeat (LRR)-containing proteins, retinoic acid-inducible gene (RIG)-like receptors (RLRs), and C-type lectin receptors (CLRs) which recognize diverse ligands such as lipopolysaccharide, peptidoglycans, zymosan, bacterial flagellae, CpG DNA, and cellsurface receptors for the $\mathrm{Fc}$ portion of antibodies and for the $\mathrm{C} 3 \mathrm{~b}$ component of complement. ${ }^{21-23}$ Activation of TLRs results in the production of both signaling molecules such as prostaglandins and cytokines/chemokines primarily through activation of the proinflammatory transcription factor nuclear factor kappa-light-chain-enhancer of activated B cells (NF- $\kappa \mathrm{B}$ ) and the NACHT, LRR, and PYD domains-containing protein 3 (NLRP3) inflammasome. ${ }^{23-25}$ These cytokines attract neutrophils, monocytes, and dendritic cells, thus accelerating phagocytosis, the synthesis of acute-phase proteins, and the initiation of the adaptive immune system toward either the cell-mediated Thelper 1 (Th1) response or the humoral/antibody T helper 2 (Th2) response. Although short-term inflammation is necessary for tissue defense, chronic and excessive activation of the innate immune system results in deleterious maladaptations and chronic inflammatory diseases such as hypertension.

\section{Monocyte/Macrophages}

Monocytes are specialized circulating cells with chemokine receptors and PRRs that facilitate quick identification and phagocytosis of endogenous bacteria and host-derived molecules generating proinflammatory cytokines and promoting immune cell recruitment. ${ }^{26}$ Macrophages are phagocytic resident cells that lead to tissue homeostasis by removing apoptotic cells and releasing growth factors. Macrophages also contain a wide range of 
PRRs which facilitate phagocytosis and are capable of presenting antigens to $\mathrm{T}$ cells by releasing cytokines and amplifying inflammation. ${ }^{21}$ Evidence for the critical role of macrophages in hypertension was shown via induction of hypertension by intravenous injection of splenic cells from hypertensive deoxycorticosterone acetate (DOCA)-salt-treated rats into normotensive rats. Biopsy of recipients' kidneys and heart showed mononuclear infiltrates in the arterial and arteriolar walls with exudative thickening of the intima, causing luminal narrowing, resistance to peripheral blood flow, and hypertension suggesting that activated innate immune cells are sufficient to impart hypertension. ${ }^{27}$

Further studies identify various conditions that activate macrophages to cause hypertension, including the RAS, high salt diet, and vascular NO inhibitors. In rodent models, the administration of angiotensin (Ang) II followed by exposure to a high-salt diet results in hypertension, cortical vasoconstriction, and increase in renal accumulation of macrophages and lymphocytes. Both mycophenolate mofetil (MMF) to block vascular and renal macrophage and lymphocyte infiltrates or selective deletion of leukocyte $\mathrm{C}-\mathrm{C}$ chemokine receptor 2 (CCR2) to inhibit MCP-1 induced vascular macrophage recruitment prevents Ang II-induced hypertension. ${ }^{28-31}$ Further studies in congenic osteopetrotic Op/Op mice which have an inherited deficiency of macrophage colony-stimulating factor and a resultant marked reduction in monocytes and macrophages have helped to clarify the the mechanistic role of these immune cells. Homozygous Op/Op mice have a blunted increase in blood pressure, reduced aortic reduced nicotinamide adenine dinucleotide phosphate (NADPH) oxidase activity, and decreased relaxation after Ang II or DOCA-salt stimulation compared to control mice. ${ }^{32,33}$ Selective ablation of lysozyme M-positive [LysM(+)] myelomonocytic cells using Cre-inducible diphtheria toxin receptor transgenic mice LysM(iDTR) reduces the number of monocytes in the circulation and limits angiotensin II-induced hypertension and infiltration of these cells into the vascular wall, while not affecting neutrophils. Adoptive transfer of wild type monocytes into depleted LysM(iDTR) mice reestablishes Ang IIinduced vascular dysfunction and hypertension whereas transfer of neutrophils does not, further supporting activated monocytes cause hypertension. ${ }^{34}$ Interestingly, recent evidence suggests a potential contrary role for macrophages in hypertension. In this model, acute salt loading increases blood pressure and macrophage accumulation in the subcutaneous tissue, producing vascular endothelial growth factor $\mathrm{C}$ and generating lymphocapillary hyperplasia in order to clear the accumulation of excess sodium in the skin. Macrophage depletion by clodronate further elevates blood pressure, suggesting an acute protective compensatory mechanism against the development of hypertension. ${ }^{35}$ The majority of hypertensive models suggest activated macrophages are an important driver of hypertension; however, this unexpected partially protective mechanism needs to be further tested under chronic conditions to assess its effect on hypertension.

\section{Reactive Oxygen Species in Monocytes/Macrophages}

The balance between reactive oxygen species (ROS) production and the antioxidant defense system determines the degree of oxidative stress. In macrophages, NADPH oxidase is a key enzyme which produces ROS to eliminate pathogens. ${ }^{36}$ Ang II or mineralocorticoids stimulate NADPH oxidase production of ROS and cytokines, ${ }^{37}$ which in turn induces a proinflammatory immune cell response by activating NF- $\kappa$ B and the NLRP3 inflammasome. 
This cycle of events leads to leukocyte and macrophage activation and more ROS generation. ${ }^{38-40}$ Renal tubulointerstitial inflammation increases intrarenal Ang II production inducing ROS generation which scavenges nitric oxide (NO) and causes increased renal vascular vasoconstriction, sodium reabsorption, and hypertension. ${ }^{41,42}$ Moreover, the role of tubulointerstitial inflammation and ROS has been supported by multiple studies showing the amelioration of hypertension with various immunosuppressants and antioxidant therapies. 43,44 Similarly, in the vessel wall, hypertension and atherosclerotic lesions are attenuated by limiting the burden of superoxide generated by myelomonocytes in $\mathrm{ApoE}^{-/-}$mice fed a high-fat diet. ${ }^{45}$ Conversely, adoptive cell transfer of monocytes in mice with selective ablation of the LysM-positive myelomonocytic cells increases the Ang II-induced oxidative burst by upregulation of NADPH oxidase, causing vascular dysfunction and hypertension. ${ }^{34}$ These studies suggest macrophage oxidative stress is a critical mechanism underlying the vascular dysfunction induced by various hypertensive stimuli.

\section{Renin-Angiotensin System and Macrophage Function}

Systemic blockade of type 1 angiotensin receptors (AT1R) lowers blood pressure, reduces progression of renal fibrosis, and improves cardiac remodeling, though the cell types that mediate these varying tissue-specific effects are not well-defined. ${ }^{46,47}$ Macrophages express nearly all components of the RAS. Expression of AT1R, angiotensin type 2 (AT2R) receptors, and angiotensin-converting enzyme (ACE) activity are increased during differentiation from monocytes to macrophages. ${ }^{48}$ Stimulation of the AT2 receptor by the selective agonist compound 21 (C21) activates mitogen-activated protein kinases (MAPKs) and extracellular signal-regulated kinase (ERK-1/2) signaling pathways promote increased interleukin (IL) 10 secretion, M2 macrophage polarization, and attenuates the macrophage pro-inflammatory phenotype in response to Ang II and lipopolysaccharide (LPS) ${ }^{49-53}$ Ang II upregulates macrophage Toll-like Receptor-4 (TLR4) expression which elicits activation of macrophage NF- $\mathrm{KB}$ signaling and promotes a pro-inflammatory M1 macrophage with the release of tumor necrosis factor alpha (TNF- $\alpha$ ) and IL-1 $\beta$ via an AT1R-dependent pathway. 54-56 Additionally, Ang II infusion stimulates myelopoiesis through AT1R and promotes accumulation of monocytes with enhanced CCR2 expression in the spleen. ${ }^{57}$ AT1R inhibition attenuates CCR2-dependent migration of monocytes isolated from hypertensive rats; thus, many investigators suggest that Ang II induces inflammation and hypertension by stimulating macrophage AT1Rs in target organs. ${ }^{48}$ To clarify the role of AT1Rs in immune cells and hypertension, many investigators have performed bone marrow (BM) transplants with donors lacking AT1Rs. However, the results are conflicting regarding effects on blood pressure, atherosclerosis, and renal damage, possibly due to the variable effects of this receptor in different immune cells and the different models used. ${ }^{58-60}$ Because these BM transplant models affect AT1R in all immune cells, subsequent investigators have evaluated the role of AT1R-specific deletions in myeloid or T cells in hypertension and renal injury. Results from both types of genetically-modified mice indicate a hypertensive response to Ang II that is similar to wild type mice mice, but with accelerated renal leukocyte infiltration and kidney damage. ${ }^{61,62}$ These suggest that in contrast to the prohypertensive actions of systemic AT1R activation, immune cell AT1R activation seems to be protective for renal injury and may not be essential for the blood pressure changes in hypertensive mouse models. Interestingly, myeloid-specific MR knockout prevents L-NAME/Ang II-mediated 
cardiac hypertrophy and fibrosis with fewer pro-inflammatory macrophages characterized by less infiltration into cardiac myocytes, but a persistent increase in blood pressure. ${ }^{63}$ These findings illustrate the intricate relationship between the RAS and macrophage phenotype in the development of hypertension.

The complexity of the interaction between the RAS and macrophages is further seen in mice overexpressing catalytically active ACE only in myeloid-derived cells, known as ACE 10/10 mice. Macrophages from ACE 10/10 mice develop much higher ACE protein expression compared to WT littermates. In contrast, neutrophils and dendritic cells marginally overexpress ACE and expression in T cells and B cells is identical to that of WT cells. ${ }^{64}$ Moreover, ACE 10/10 mice have reduced lung ACE and absent endothelial and renal ACE expression, but plasma ACE levels are similar to WT littermates. ${ }^{64}$ Interestingly, these animals have normal blood pressure, and a blunted blood pressure response to L-NAME and Ang II infusion despite a more robust macrophage pro-inflammatory cytokine response to lipopolysaccharide. ${ }^{65}$ In ACE 10/10 mice, the usual accumulation of sodium and water retention in response to high serum Ang II is prevented by absent renal ACE expression, suggesting that the impact of intrarenal RAS overcomes the pro-inflammatory macrophage phenotype in this unique model. ${ }^{65,66}$ Overall, the capability of activated macrophages to cause hypertension is dependent upon the hypertensive stimuli, interaction with the remaining immune cells, and compensatory mechanisms of tissues involved in the hypertensive response (Figure 1).

\section{Neutrophils}

Neutrophils are a type of myeloid cell that makes up the highest proportion of circulating leukocytes. These innate immune cells are the first line of defense for bacterial infection, but their role in the chronic inflammation associated with hypertension is less well-defined. ${ }^{67}$ One promising mechanism by which neutrophils may mediate hypertension is through myeloperoxidase (MPO). Myeloperoxidase is a member of the superfamily of heme peroxidases that is expressed predominantly in neutrophils and monocytes and generates reactive oxidants and radical species that carry out lipid peroxidation. It is enriched in human atherosclerotic plaques, but may also have a role in hypertension, serving as a catalytic sink for nitric oxide. ${ }^{68} \mathrm{MPO}$-generated hypochlorous acid reacts with $\mathrm{L}$-arginine to produce products that adversely affect endothelial function by inhibiting nitric oxide (NO) formation and acetylcholine-induced aortic relaxation in animal models. ${ }^{69}$ Hypochlorous acid has also been demonstrated to modify high density lipoprotein and subsequently displace endothelial nitric oxide synthase (NOS) from its usual plasma membrane location, thus attenuating its activity. ${ }^{70}$ Both MPO and hypochlorous acid reduce the availability of a critical NOS cofactor, NADPH. ${ }^{71}$ These effects were demonstrated in vivo in a murine model of MPO knockout, where mice were protected from toxemia-induced impairment of endothelial-dependent vascular relaxation, ${ }^{72}$ and in a pig model that demonstrated reduced arterial blood flow in response to MPO injection. ${ }^{73}$ These findings suggest a role for MPO in the control of hypertension and its pathway as a possible target for therapeutic intervention in hypertension and cardiovascular disease. 


\section{Dendritic Cells}

Dendritic cells are bone-marrow-derived cells that can be found in the blood, lymphoid organs, and tissues. These professional antigen-presenting cells effectively serve as a bridge between the innate and adaptive immune systems to activate $\mathrm{T}$ lymphocytes and modulate inflammatory responses. ${ }^{74}$ Classification of dendritic cells can vary but generally consists of plasmacytoid dendritic cells and 2 classes of conventional dendritic cells, though dendritic cells can also derive from the monocyte lineage. Several mouse models have demonstrated the necessity of dendritic cells in the development of Ang II-responsive hypertension, including transgenic mice with ablation of CD11-positive dendritic cells and those with knockout of Fms-like tyrosine kinase 3 ligand that allows for the development of conventional dendritic cells. ${ }^{75,76}$ Interestingly, AT1R seems to influence dendritic cell differentiation. Deletion of AT1R results in dendritic cells with lower levels of inflammatory cytokine production and reduced activation in response to lipopolysaccharide ${ }^{77}$ suggesting a critical interaction between dendritic cells and the renin angiotensin system.

Multiple mechanisms have been identified by which dendritic cells affect $\mathrm{T}$ cell activation to influence blood pressure. $\mathrm{T}$ cell activation requires not only antigen presentation to the $\mathrm{T}$ cell receptor through a major histocompatibility complex, but also further costimulatory interaction between the dendritic cell and the $T$ cell. Naïve $T$ cell activation requires costimulation via the interaction of B7 ligands (CD80 and CD86) on dendritic cells with CD27 on T cells. Ang II-induced hypertension in mice increases expression of CD86 in dendritic cells. Blocking B7-dependent costimulation or deletion of the B7 ligands reduces Ang II-induced or DOCA salt-induced hypertension, and in fact, established hypertension is reversible with blockage of the costimulation. ${ }^{78}$ Similarly, costimulatory interaction of CD70 on dendritic cells with CD27 on T cells is necessary for memory $\mathrm{T}$ cell formation. A mouse model of repeated hypertensive challenge results in increased expression of dendritic cell CD70 and subsequent accumulation of memory T cells in the kidney and bone marrow that secrete interferon gamma (IFN $\gamma$ ) and IL-17A, both cytokines known to be associated with hypertension. Mice subsequently demonstrate salt-sensitive hypertension associated with accumulation of bone marrow memory $\mathrm{T}$ cells and their expansion to the kidney. These hypertensive and memory $\mathrm{T}$ cell responses are eliminated with knockout of CD70. ${ }^{79}$ Aldosterone similarly activates dendritic cells, with subsequent augmentation of IL-17producing $\mathrm{T}$ cells that can be prevented with mineralocorticoid receptor antagonists. ${ }^{80}$ Conversely, the ubiquitin-editing protein A20 in dendritic cells seems to limit T cell activation. Heterozygous deletion of A20 in CD11c-positive dendritic cells in mice leads to an exaggerated hypertensive response to low-dose Ang II infusion, as well as increased numbers of TNFa and IFN $\gamma$ secreting memory T cells in the kidney. ${ }^{81}$ Together these findings suggest a vital role for dendritic cells in the T cell activation that mediates hypertension.

The observations of the interactions between dendritic cells and memory $\mathrm{T}$ cells have led to the concept that hypertension may be due to antigen-mediated rather than inflammationmediated responses, with dendritic cell activation by neoantigens. One possible source of these neoantigens is through isolevuglandins, a group of highly reactive gammaketoaldehydes. In a murine model of Ang II-induced hypertension, dendritic cells produce 
increased quantities of superoxide, leading to the accumulation of isolevuglandin-modified proteins that act as neoantigens. These dendritic cells also have increased expression of B7 ligands and produce cytokines that trigger the activation and proliferation of $\mathrm{T}$ cells that produce IL-17A, TNFa, and IFN $\gamma$, all of which contribute to hypertension. ${ }^{82}$ Furthermore, adoptive transfer of activated dendritic cells induces hypertension in response to low doses of Ang II and isolevuglandin scavengers to attenuate hypertension. These results were confirmed by a study that demonstrated that sodium entry into dendritic cells through amiloride-sensitive channels triggers activation of protein kinase $\mathrm{C}$ and subsequent isolevuglandin formation to cause downstream $\mathrm{T}$ cell activation and hypertension. ${ }^{83}$ This mechanism identifies isolevuglandin scavengers as a potential new target for hypertension therapy.

\section{T and B Lymphocytes}

$\mathrm{T}$ and B lymphocytes are critical components of adaptive immunity that both influence, and are influenced by the innate immune system. The innate immune system's antigen presenting cells (dendritic cells, macrophages, innate-like B cells, and others) tailor the differentiation and adaptive response of $\mathrm{T}$ cells to an antigen. ${ }^{84}$ Additionally, lymphocytes share features of innate immunity such as antigen and cytokine recognition in both $\mathrm{B}$ and $\mathrm{T}$ cells, and the presence of diverse TLR on T lymphocytes. ${ }^{85}$ In this section, we will describe multiple studies demonstrating the role of adaptive immunity in the development of hypertension.

\section{T Lymphocytes}

T cells mature in the thymus and move to lymphoid organs such as spleen and lymph nodes where they remain in a dormant state until an antigen presenting cell triggers them. T cells have been implicated in hypertension through several mechanisms including cytokine production and activation and infiltration of the renal vasculature and central nervous system. The thymus is a critical organ for development and education of T cells. Early studies in athymic mice showed that lymphocyte depletion in multiple mouse models of hypertension results in the prevention or correction of hypertension. ${ }^{2,86-88}$ Interestingly, athymic DOCA-treated mice are resistant to salt-induced hypertension, but transplantation of the thymus restores their salt-sensitivity. ${ }^{2}$ Sprague-Dawley rats typically have a hypertensive response to partial renal infarction, but this hypertensive response is attenuated by treatment with the immunosuppressant cyclophosphamide. Similar results occurred in genetically hypertensive rats of the Lyon strain. ${ }^{7,89}$ Moreover, the transfer of lymph node cells from rats with renal infarction or splenocytes from DOCA-salt-treated rats to normal rats increases blood pressure in the recipient, suggesting that an intact $\mathrm{T}$ cell immune system is required for the development of hypertension. ${ }^{27,90}$

The importance of $\mathrm{T}$ cells in hypertension is evident in recombinase activating gene knockout (RAG-1 ${ }^{-1-}$ ) mice which lack B and T cells. RAG- $1^{-1-}$ mice develop blunted hypertension in response to either Ang II, DOCA-salt, or norepinephrine challenge. ${ }^{91-93}$ Restoration of CD8+ T cells but not B cells into RAG- $1^{-/-}$mice induce sodium and water retention restoring the hypertensive response to these stimuli, indicating that $\mathrm{CD} 8+\mathrm{T}$ cells 
may be necessary for aspects of the hypertensive response. ${ }^{91,92}$ Further evidence of the importance of $\mathrm{T}$ cells in the development of hypertension is also shown in mice with severe combined immune deficiency (SCID) and in Dahl-salt sensitive rats with selective removal of CD247, a gene important in T cell signaling, both of which are protected from hypertension despite hypertensive stimuli. ${ }^{94,95}$ Interestingly, more recent generations of RAG- $1^{-/-}$mice that were resistant to Ang-II-induced-hypertension have now lost this characteristic despite continued T-cell deficiency. This seems to be related to possibly adaptive spontaneous mutations and genetic drift leading to increased renal sensitivity to angiotensin II. ${ }^{96}$ Other investigators postulate that this loss of resistance to Ang II infusion could be due to increased natual killer cell degranulation and cytokine production independently of $\mathrm{T}$ and $\mathrm{B}$ cell lymphopenia. ${ }^{97,98}$ This theory is based on previous literature suggesting that increased natural killer cell cytotoxicity impairs placental vascular remodeling and spiral artery formation, leading to hypertension in pregnant women. ${ }^{99,100}$ The evolving responsiveness of RAG-1 $1^{-/}$mice to Ang II infusion within the same background presents a unique opportunity for further research exploring the mechanism(s) by which T-cell interactions with other immune cells can mediate hypertension.

Mechanistically, CD4+ and CD8+ T cells invade the kidney and vasculature during hypertension, causing endothelial dysfunction and inappropriate sodium retention in the kidney. This is mediated through several putative pathways, including ROS development and the release of pro-inflammatory cytokines. ${ }^{91,94,101}$ Ang II induces ROS in T cells via NADPH oxidase. In RAG1 ${ }^{-/-}$mice, adoptive transfer of T cells lacking the AT1R or functional NADPH oxidase results in blunted Ang II-dependent hypertension and decreased aortic superoxide production compared to WT T cell recipients, emphasizing the importance of ROS generated by T cells in Ang II-induced hypertension. ${ }^{91}$ Cytokine secretion profiles from $\mathrm{T}$ cells have also shown to be important in the development of hypertension and may mediate ROS generation. T cells secrete TNFa, a potent pro-inflammatory cytokine that induces ROS production and activates sodium retention to cause hypertension. ${ }^{91,102}$ Administration of the TNFa antagonist, etanercept, prevents Ang II-induced hypertension and fructose-fed-mediated hypertension, supporting a role for TNFa in the pathogenesis of hypertension. ${ }^{62,103,104}$ Moreover, deletion of both IFN- $\gamma$ and IL-17 significantly reduces elevated blood pressure in Ang-II-induced hypertension models by disrupting tubular sodium reabsorption. ${ }^{105,106}$ In contrast, a recent study in a combined model of DOCA-salt and Ang-II-induced hypertension demonstrates that combined IL-17/IL-23 deficiency does not suppress the blood pressure response, illustrating the complex role of the immune system within diverse models of hypertension. ${ }^{107}$ Multiple other cytokines are associated with hypertension and inflammation, including IL-8, IL-12, IL-15, and IL-18, but more recently IL-22 has shown a stronger link. ${ }^{108}$ The CC genotype of IL-22 gene polymorphism is an independent risk factor for hypertension in patients with CAD, while the GG genotype has a protective effect. ${ }^{109}$ In mice, treatment with recombinant IL-22 increases blood pressure, whereas anti-IL-22 neutralizing monoclonal antibody decreases blood pressure, inflammatory responses, and endothelial dysfunction. ${ }^{110}$ There may be a future for the use of monoclonal neutralizing antibodies for the treatment of hypertension, but the current side effects associated with systemic use are problematic, and the development of tissue-selective options will likely be critical. 
Several promising studies point toward $\mathrm{T}$ regulatory cells as overall regulators of the immune response, and thus regulators of hypertension. T regulatory (Treg) cells, a subset of CD4+ cells important for the suppression of innate and adaptive immune responses, are specifically recognized to be important in blood pressure regulation. ${ }^{111}$ Adoptive transfer of Treg cells, but not $\mathrm{T}$ effector cells $\left(\mathrm{CD} 4^{+} \mathrm{CD} 25^{-}\right)$, reduces hypertension induced by Ang II or aldosterone infusions. ${ }^{112-114}$ Moreover, in RAG1 ${ }^{-/-}$mice, adoptive transfer of Treg cells prevents Ang II-induced hypertension, vascular damage, and immune cell infiltration. Conversely, the adoptive transfer of $\mathrm{T}$ cells from Scurfy mice, which lack Treg cells, into $\mathrm{RAG}^{-/-}$mice exacerbates Ang II-induced microvascular endothelial dysfunction, oxidative stress, and inflammation. ${ }^{115}$ Further evidence of the regulatory role of Treg cells in hypertension was tested in SSBN2 rats, a Dahl salt-sensitive hypertensive rodent model genetically modified by substitution of chromosome 2 from a normotensive strain. This genetic modification is associated with improved Treg function and leads to reduced hypertension, less vascular hypertrophy, and reduced aortic inflammation compared to Dahl salt-sensitive rats. ${ }^{116}$ These studies in different rodent models emphasize the unique role of the Treg subtype in hypertension regulation and represent a promising target for immunomodulatory medications to control hypertension.

\section{B Lymphocytes}

B lymphocytes are critical for adaptive immunity, via their ability to detect and process antigens and produce antibodies. Several studies report high levels of IgG, IgM and IgA antibodies in severely hypertensive individuals. ${ }^{117,118}$ In rodents Ang II infusion in mice increases the number of splenic B cells and circulating IgGs, and causes marked IgG accumulation in the aortic adventitia. Moreover, multiple studies have shown that depletion/ modulation of B cell activity through immune modulation (i.e. rituximab) or knockout models such as B cell activating factor receptor knockout (BAFF- $\mathrm{R}^{-/}$) mice can reduce mean arterial pressure and the hypertensive response to Ang II. ${ }^{19120}$ Alternative agents such as bortezomib, a proteasome inhibitor which lowers plasma cell antibody production, have shown a promising ability to reduce bone marrow plasma cells in a murine model of SLE mice. Mice treated with bortezomib have decreased renal injury/glomerulosclerosis, reduced $\mathrm{B}$ and $\mathrm{T}$ lymphocyte infiltration into the kidney, and decreased mean arterial pressure. ${ }^{120}$ These findings are somewhat conflicting with previous literature suggesting that Ang-II-induced hypertension is restored in RAG-1 ${ }^{-/-}$mice after adoptive transfer of $\mathrm{T}$ cells but not B cells. ${ }^{119}$ However, this apparent discrepancy could imply that B cell activation requires interaction with $\mathrm{T}$ cells, and the two type of cells may have different mechanisms of inducing hypertension (Figure 2).

\section{Activation of Immune Cells in Hypertension}

The innate immune system senses microbial infection (PAMPs) and host-derived endogenous molecules that arise due to cell death (DAMPs) using pattern recognition receptors. TLRs and NOD-like receptor family pyrin domain-containing protein (NLRP) are sentinel pattern recognition receptors of the innate immune system that help initiate the inflammatory response and are linked to hypertension. ${ }^{21,23,24,121}$. Activation of TLR domain adaptors facilitate cytokine production and stimulation of adaptive immunity via activation 
of IRF3, NF- $\kappa$ B, or MAPKs. ${ }^{37,122}$ Evidence for innate immune cell TLR as a driver of hypertension has been shown in isolated splenocytes from spontaneously hypertensive rats (SHR). Splenocytes pretreated with Ang II or nicotine have higher TNF-a, IL-10, and IL-6 release in response to TLR7/8 and 9 ligand stimulation. In contrast, in a model of nonhypertensive rats, splenocyte response to TLR stimulation was completely different.

Nicotine mitigated the cytokine response, and Ang II had no effect suggesting that in models predisposed to hypertension, neurohormonal regulation of innate immunity seems to induce hypertension via TLR stimulation. ${ }^{123}$ There is additional evidence for the involvement of macrophage TLR4 in the development of hypertension. Patients with hypertension had higher TLR4 mRNA expression in monocytes compared to normotensive subjects, and intensive hypertensive treatment decreased TLR4 levels. ${ }^{124}$ Multiple studies have blocked the effects of TLR4 locally, systemically, and in the central nervous system to clarify its role in the development of hypertension. In rats, antibody blockade of TLR4 lowers blood pressure in SHR ${ }^{125}$ and DOCA-salt rats but not in Ang II-infused rats ${ }^{126,127}$ except when TLR4 is antagonized within the periventricular nuclei ${ }^{128}$ suggesting that central TLR4 plays an important role in blood pressure regulation. Furthermore, mice lacking the gene for TLR4 have an attenuated blood pressure response to Ang II and L-NAME infusion in mice suggesting that the TLR4-mediated blood pressure regulation varies accordingly to the animal model and stimuli, but that TLR4 in the central nervous system seems to be essential to Ang-II-mediated hypertension ${ }^{129-131}$ Finally, the NLRP3 Inflammasome is a crucial mediator of inflammation in several chronic inflammatory diseases. Inflammasomes are multimeric complexes that facilitate caspase-1-mediated processing of the pro-inflammatory cytokines IL-1 $\beta$ and IL-18. In mice with hypertension induced by unilateral nephrectomy, treatment with DOCA-salt is associated with an increase in inflammasome expression and/or activity in the kidneys. ${ }^{132}$ Furthermore, genetic deficiency in the adaptor protein, ASC, or use of an NLRP3 inhibitor reduces renal inflammation, fibrosis, and hypertension in this mouse model, suggesting that inhibition of the NLRP3 inflammasome could be an antihypertensive strategy. ${ }^{132,133}$ These studies indicate that activation of immune cell PRRs increase ROS, tissue damage, and hypertension and induce a vicious cycle. Early studies using inflammasone ihibitors have passed phase 1 , and there is anticipation of further studies in many chronic inflammatory diseases. ${ }^{134}$

\section{Immunity and Target Organs in Hypertension}

\section{Immunity and Vascular Wall}

Vascular tone and arterial stiffness are regulated by a number of mediators such as Ang II, aldosterone, cytokines, and shear stress, all of which stimulate ROS production by NADPH oxidases which reduces nitric oxide (NO), and induces vasoconstriction. Vascular ROS also increase metalloproteinases, tumor grow factor beta (TGF- $\beta$ ), and endothelial proinflammatory cytokines, which promote vascular fibrosis and adventitial immune cell accumulation to increase ROS production, endothelial dysfunction, and vasoconstriction. 91,114,135-138 Infusion of a cell-permeant inhibitor of NADPH oxidase suppresses leukocyte infiltration and vascular hyperthrophy induced by Ang II independently of the blood pressure changes (Figure 3). ${ }^{139}$ Moreover, depletion of monocytes/macrophages using Creinducible diphtheria toxin receptor transgenic mice significantly reduces aortic superoxide 
production, vascular dysfunction, and blood pressure during Ang II-induced hypertension. ${ }^{34}$ In contrast, adoptive transfer of WT, but not NADPH oxidase-null monocytes, into these depleted mice restores vascular oxidative stress and hypertension suggesting that NADPH generated by monocytes is a important mechanism by which Ang II mediates hypertension.

${ }^{34}$ Another major function of vascular macrophage deposition, particularly the M2 macropahge subtype, is to promote extracellular matrix remodeling by regulating TGF- $\beta$ production upon B-cell stimulation. ${ }^{119}$ Ang II-induced increases in aortic pulse wave velocity, vascular TGF- $\beta$ expression, M2 macrophage numbers, and IgG deposition are attenuated in a B cell knockout model (BAFF- $\mathrm{R}^{-/-}$) mice. IgG purified from Ang II- but not saline-treated mice induce the production of TGF- $\beta$ from cultured murine macrophages, suggesting an important interaction between B cells and vascular macropahges in the regulation of vascular stiffness and hypertension.

$\mathrm{T}$ cells also play an active role in the vasculature. Activated $\mathrm{T}$ cells induce hypertrophy and fibrosis of the aorta, as well as superoxide accumulation in the aortic wall. This leads to arterial inflammation and stiffness which drives hypertension. ${ }^{114,140-142}$ Treg cells seem to be protective for hypertension, as their adoptive transfer into C57BL/6 mice prevents aldosterone or Ang II-induced hypertension. ${ }^{112,114}$ Additionally, these mice do not develop mesenteric artery hypertrophy by aldosterone and have reduced aldosterone-induced oxidative stress and aortic periadentitial/adventitial monocyte/macrophage infiltration. Mechanistically, Treg cells and other immune cells produce IL-10, an anti-inflammatory cytokine that regulates adaptive immunity, and IL- $10^{-/-}$mice show increased mean arterial pressure and increased aortic vascular constriction to phenylephrine compared to WT. ${ }^{143}$ Together these data indicate that chronic immune activation in the vessel wall promotes functional and structural alterations of resistance arteries that are key mechanisms for the development of hypertension and its complications.

\section{Immunity and Kidney}

In both humans with hypertension and various murine models of hypertension, tubulointerstitial infiltration of leukocytes is common. ${ }^{144}$ Immunosuppressive drugs (MMF, rapamycin, cyclosporine A), inhibition of pro-inflammatory NF- $\mathrm{KB},{ }^{145}$ and IL-6 depletion all result in amelioration of hypertension in multiple animal models. ${ }^{146}$ However, there is controversy regarding whether renal infiltration of immunocompetent $\mathrm{T}$ cells is the cause or consequence of hypertension. Evidence for the causal role comes from a prehypertensive model of SHR at 3 weeks of age in which increased renal immune infiltrates precede the onset of hypertension. The renal interstitium of these animals shows increased lymphocyte and macrophage accumulation as well as Ang II-positive tubular cells expressing activated NF- $\kappa B$ with no glomerular changes. At 24-weeks, SHR mice are hypertensive with striking increase in both the CD4/CD8 ratio and NF- $\mathrm{KB}$ activation, suggesting that renal immune cells promote the enviroment that drives hypertension in the SHR model. ${ }^{145}$ Furthermore, in normotensive rats, L-NAME-induced hypertension and tubulointerstitial lymphocytic infiltrates are prevented by administration of MMF, also supporting a critical role for these cells in the development of hypertension. ${ }^{147}$ Both $\mathrm{Rag}^{-/-}$mice lacking lymphocytes and Id $2^{-/-}$mice lacking splenic CD8a, dendritic cells, and CD8 ${ }^{+}$memory $\mathrm{T}$ cells confirm this role since both mouse models are unresponsive to Ang II-induced hypertension. ${ }^{91,148}$ 
Furthermore, adoptive transfer of $\mathrm{T}$ cells but not $\mathrm{B}$ cells restores responsiveness to Ang II and induces renal infiltrates in $\mathrm{Rag}^{-/-}$mice. IL-17 produced by $\mathrm{CD}^{+} \mathrm{T}$ helper cells is likely important in the pathogenesis of hypertension in response to Ang II infusion by increasing the expression of serum and glucocorticoid regulated kinase 1 in the proximal tubule leading to increased abundance of the renal sodium hydrogen exchanger 3 expression. ${ }^{149,150}$ Conversely, IL-17 ${ }^{-/}$mice do not develop vascular dysfunction, renal injury, or hypertension in response to Ang II infusion. ${ }^{106,150}$ IFN $\gamma$ secretion by $\mathrm{CD}^{+}$cells from mice with the absence of mineralocorticoid receptor promote hypertension through local inflammation in target organs such as the kidney and aorta. ${ }^{151}$ Interestingly, both IL-17 and IFN $\gamma$ affect expression of luminal transporters in nephrons, showing how increased cytokine production by $\mathrm{T}$ cells can lead to impaired natriuresis and contribute to hypertension. ${ }^{152}$

Increased renal monocyte/macrophage proliferation also occurs in multiple models of hypertension. Immunosuppressive therapies minimize the increase in blood pressure and the amount of infiltrated macrophages in the kidneys. ${ }^{153,154}$ Ang II increases renal oxidative stress and monocyte/macrophage infiltration into the kidneys, causing inflammation and renal fibrosis, ${ }^{95,155}$ while reduced recruitment of renal macrophages by CCR2 knockout attenuates Ang II-induced renal injury. ${ }^{29,31}$ Several studies in hypertensive modes with genetic modification to reduce macrophages show improved endothelial function and reduced vascular oxidative stress and remodeling. ${ }^{34,156-158}$ Similarly, monocyte/macrophage depletion with chlodrate in Ang II and Dahl salt-sensitive murine models of hypertension significantly attenuates systolic blood pressure elevation and renal injury and fibrosis, together suggesting that suppression of inflammation could be a potential therapeutic target to reduce the adverse consequences of hypertensive renal diseases. 159

Overall, renal inflammation mediated by both lymphocytes and macrophages promotes intrarenal Ang II generation, favoring further leukocyte infiltration and oxidative stress. Increased oxidative stress reduces NO bioavailability and contributes importantly to the reduction of medullary blood flow, reduced sodium excretion, and hypertension. Furthermore, decreased NO from medullar oxidative stress accelerates interstitial fibrosis and progressive kidney damage (Figure 4). ${ }^{41,42,160,161}$

\section{Immunity and Central Nervous System (CNS)}

Immune cells within the central nervous system (microglia), and outside the blood-brain barrier in the choroid plexus, meninges, and perivascular space are known to be involved in the development of hypertension. ${ }^{162}$ The link between microglial activation and hypertension is demonstrated in mice with depletion of microglia cells through either intracerebroventricular injections of the antibiotic minocycline, which inhibits microglial cells, or Cre-inducible CD11b-diphtheria toxin receptor transgenic mice. Both types of mice have decreased neuroinflammation and reduced blood pressure response to Ang II and LNAME. ${ }^{163}$ Perivascular macrophages (PVM) also influence blood pressure regulation. In the stroke-prone SHR model, depletion of PVM with intracerebral clodronate treatment ameliorates hypertension by supression of the sympathetic nerve activation. ${ }^{164,165}$

Several areas of the brain sense hypertensive stimuli and modulate the autonomic nervous system. ${ }^{166}$ Sympathetic nervous system (SNS) activation is controlled by the forebrain and 
hindbrain nuclei, particularly by the paraventricular nucleus of the hypothalamus (PVN), the circumventricular organs (CVOs), the rostral ventral lateral medulla (RVLM), the anteroventral third ventricle, and the nucleus of the solitary tract, all of which have AT1Rs. Ang II activation of the AT1R increases ROS production and pro-inflammatory cytokines (IL-1 $\beta$, IL-6, TNF- $a$ ) and suppresses IL-10 expression in the PVN and RVLM. ${ }^{167-169}$ This inflammatory response in the PVN and RVLM results in elevated SNS activity and cytokine signaling activation in the CVOs to induce hypertension. Treatment of SHRs with AT1R blockers reverse cerebrovascular inflammation by reducing macrophage infiltration, endothelial NO synthase, heat shock protein upregulation, and inflammatory molecules including TNF-a, IL-1, and intercellular adhesion molecules. ${ }^{170}$ Thus, Ang II inducedinflammation interacts with the SNS to contribute to the development of hypertension.

The parasympathetic nervous system also interacts with immune cells. Lymphocytes and myeloid cells express nicotinic and muscarinic receptors, as well as adrenergic receptors.171 The vagus nerve is vital in informing the brain of the peripheral immune status and controlling the activity of immune cells. Vagal stimulation mediated by the a-7-nicotinic acetylcholine receptor potentiates an anti-inflammatory macrophage phenotype by reducing TNF- $\alpha$, IL-1 $\beta$, and IL-6 release, ${ }^{172,173}$ while increased splenic and renal sympathetic output promotes a pro-inflammatory response, suggesting that during hypertension there is a peripheral autonomic imbalance causing an increase in cytokines that feed-forward to more CNS inflammation and sympathetic nervous system activation. Overall, these studies suggest that activation of microglia by different hypertensive stimuli increases proinflammatory cytokine production in hypothalamic regions around the third and fourth ventricles to activate the SNS, which contributes to increased systemic immune cell activation and cytokine release, perpetuating chronic inflammation and hypertension (Figure $5)$.

\section{Conclusion}

The studies presented here highlight the importance of immunity as a common thread underlying the various mechanisms of hypertension across many organ systems Exploring the genetic and environmental factors that predispose these cells to react to common stimuli and achieving a deeper understanding of the mechanisms by which immune cells communicate with target organs to cause hypertension will allow us to develop new therapies for this pervasive disease.

\section{Acknowledgements}

This work was supported by NIH R01HL09481806, VA Merit Award 1BX003648-01. The contents of this article are solely the responsibility of the authors and do not necessarily represent the official view of NIH.

\section{References}

1. Nwankwo T, Yoon SS, Burt V, Gu Q. Hypertension among adults in the United States: National Health and Nutrition Examination Survey, 2011-2012. NCHS data brief. 2013(133):1-8.

2. Svendsen UG. Evidence for an initial, thymus independent and a chronic, thymus dependent phase of DOCA and salt hypertension in mice. Acta Pathol Microbiol Scand A. 1976;84(6):523-528. [PubMed: 998251] 
3. Rodriguez-Iturbe B, Pons H, Johnson RJ. Role of the Immune System in Hypertension. Physiol Rev. 2017;97(3):1127-1164. [PubMed: 28566539]

4. Harrison DG, Marvar PJ, Titze JM. Vascular inflammatory cells in hypertension. Front Physiol. 2012;3:128. [PubMed: 22586409]

5. White FN, Grollman A. Autoimmune Factors Associated with Infarction of the Kidney. Nephron. 1964;1:93-102. [PubMed: 14248727]

6. Dzielak DJ. Immune mechanisms in experimental and essential hypertension. Am J Physiol. 1991;260(3 Pt 2):R459-467. [PubMed: 2000994]

7. Bataillard A, Vincent M, Sassard J, Touraine JL. Antihypertensive effect of an immunosuppressive agent, cyclophosphamide, in genetically hypertensive rats of the Lyon strain. Int $\mathbf{J}$ Immunopharmacol 1989;11(4):377-384. [PubMed: 2777432]

8. Bendich A, Belisle EH, Strausser HR. Immune system modulation and its effect on the blood pressure of the spontaneously hypertensive male and female rat. Biochem Biophys Res Commun 1981;99(2):600-607. [PubMed: 6972216]

9. Ba D, Takeichi N, Kodama T, Kobayashi H. Restoration of T cell depression and suppression of blood pressure in spontaneously hypertensive rats (SHR) by thymus grafts or thymus extracts. J Immunol 1982;128(3):1211-1216. [PubMed: 6120194]

10. Khraibi AA, Smith TL, Hutchins PM, Lynch CD, Dusseau JW. Thymectomy delays the development of hypertension in Okamoto spontaneously hypertensive rats. J Hypertens. 1987;5(5):537-541. [PubMed: 3429859]

11. De Miguel C, Das S, Lund H, Mattson DL. T lymphocytes mediate hypertension and kidney damage in Dahl salt-sensitive rats. Am J Physiol Regul Integr Comp Physiol 2010;298(4):R11361142. [PubMed: 20147611]

12. Mattson DL, James L, Berdan EA, Meister CJ. Immune suppression attenuates hypertension and renal disease in the Dahl salt-sensitive rat. Hypertension. 2006;48(1):149-156. [PubMed: 16754791]

13. Hughson MD, Gobe GC, Hoy WE, Manning RD Jr., Douglas-Denton R, Bertram JF. Associations of glomerular number and birth weight with clinicopathological features of African Americans and whites. Am J Kidney Dis. 2008;52(1):18-28. [PubMed: 18514988]

14. Sung KC, Suh JY, Kim BS, et al. High sensitivity C-reactive protein as an independent risk factor for essential hypertension. Am J Hypertens. 2003;16(6):429-433. [PubMed: 12799089]

15. Bautista LE, Vera LM, Arenas IA, Gamarra G. Independent association between inflammatory markers (C-reactive protein, interleukin-6, and TNF-alpha) and essential hypertension. J Hum Hypertens. 2005;19(2):149-154. [PubMed: 15361891]

16. Sesso HD, Buring JE, Rifai N, Blake GJ, Gaziano JM, Ridker PM. C-reactive protein and the risk of developing hypertension. JAMA. 2003;290(22):2945-2951. [PubMed: 14665655]

17. Mattace-Raso FU, Verwoert GC, Hofman A, Witteman JC. Inflammation and incident-isolated systolic hypertension in older adults: the Rotterdam study. J Hypertens. 2010;28(5):892-895. [PubMed: 20375909]

18. Sesso HD, Wang L, Buring JE, Ridker PM, Gaziano JM. Comparison of interleukin-6 and Creactive protein for the risk of developing hypertension in women. Hypertension. 2007;49(2):304310. [PubMed: 17159088]

19. Matzinger P The danger model: a renewed sense of self. Science. 2002;296(5566):301-305. [PubMed: 11951032]

20. Matzinger P Tolerance, danger, and the extended family. Annu Rev Immunol. 1994;12:991-1045. [PubMed: 8011301]

21. Akira S, Uematsu S, Takeuchi O. Pathogen recognition and innate immunity. Cell. 2006;124(4):783-801. [PubMed: 16497588]

22. Takeuchi O, Akira S. Pattern recognition receptors and inflammation. Cell. 2010;140(6):805-820. [PubMed: 20303872]

23. Schroder K, Tschopp J. The inflammasomes. Cell. 2010;140(6):821-832. [PubMed: 20303873]

24. McCarthy CG, Goulopoulou S, Wenceslau CF, Spitler K, Matsumoto T, Webb RC. Toll-like receptors and damage-associated molecular patterns: novel links between inflammation and hypertension. Am J Physiol Heart Circ Physiol. 2014;306(2):H184-196. [PubMed: 24163075] 
25. Kelley N, Jeltema D, Duan Y, He Y. The NLRP3 Inflammasome: An Overview of Mechanisms of Activation and Regulation. Int J Mol Sci. 2019;20(13).

26. Serbina NV, Jia T, Hohl TM, Pamer EG. Monocyte-mediated defense against microbial pathogens. Annu Rev Immunol. 2008;26:421-452. [PubMed: 18303997]

27. Olsen F Transfer of arterial hypertension by splenic cells from DOCA-salt hypertensive and renal hypertensive rats to normotensive recipients. Acta Pathol Microbiol Scand C. 1980;88(1):1-5. [PubMed: 7376880]

28. Franco M, Martinez F, Rodriguez-Iturbe B, et al. Angiotensin II, interstitial inflammation, and the pathogenesis of salt-sensitive hypertension. Am J Physiol Renal Physiol. 2006;291(6):F12811287. [PubMed: 16868307]

29. Elmarakby AA, Quigley JE, Olearczyk JJ, et al. Chemokine receptor $2 b$ inhibition provides renal protection in angiotensin II - salt hypertension. Hypertension. 2007;50(6):1069-1076. [PubMed: 17938380]

30. Ishibashi M, Hiasa K, Zhao Q, et al. Critical role of monocyte chemoattractant protein-1 receptor CCR2 on monocytes in hypertension-induced vascular inflammation and remodeling. Circ Res. 2004;94(9):1203-1210. [PubMed: 15059935]

31. Liao TD, Yang XP, Liu YH, et al. Role of inflammation in the development of renal damage and dysfunction in angiotensin II-induced hypertension. Hypertension. 2008;52(2):256-263. [PubMed: 18541733]

32. De Ciuceis C, Amiri F, Brassard P, Endemann DH, Touyz RM, Schiffrin EL. Reduced vascular remodeling, endothelial dysfunction, and oxidative stress in resistance arteries of angiotensin IIinfused macrophage colony-stimulating factor-deficient mice: evidence for a role in inflammation in angiotensin-induced vascular injury. Arterioscler Thromb Vasc Biol. 2005;25(10):2106-2113. [PubMed: 16100037]

33. Ko EA, Amiri F, Pandey NR, et al. Resistance artery remodeling in deoxycorticosterone acetatesalt hypertension is dependent on vascular inflammation: evidence from m-CSF-deficient mice. Am J Physiol Heart Circ Physiol. 2007;292(4):H1789-1795. [PubMed: 17142347]

34. Wenzel P, Knorr M, Kossmann S, et al. Lysozyme M-positive monocytes mediate angiotensin IIinduced arterial hypertension and vascular dysfunction. Circulation. 2011;124(12):1370-1381. [PubMed: 21875910]

35. Machnik A, Neuhofer W, Jantsch J, et al. Macrophages regulate salt-dependent volume and blood pressure by a vascular endothelial growth factor-C-dependent buffering mechanism. Nat Med. 2009;15(5):545-552. [PubMed: 19412173]

36. Castaneda OA, Lee SC, Ho CT, Huang TC. Macrophages in oxidative stress and models to evaluate the antioxidant function of dietary natural compounds. J Food Drug Anal. 2017;25(1):111-118. [PubMed: 28911528]

37. Mian MO, Paradis P, Schiffrin EL. Innate immunity in hypertension. Current hypertension reports. 2014;16(2):413. [PubMed: 24407446]

38. Anderson MT, Staal FJ, Gitler C, Herzenberg LA, Herzenberg LA. Separation of oxidant-initiated and redox-regulated steps in the NF-kappa B signal transduction pathway. Proc Natl Acad Sci U S A. 1994;91(24):11527-11531. [PubMed: 7526398]

39. Zhou R, Tardivel A, Thorens B, Choi I, Tschopp J. Thioredoxin-interacting protein links oxidative stress to inflammasome activation. Nature immunology. 2010;11(2):136-140. [PubMed: 20023662]

40. Zhou R, Yazdi AS, Menu P, Tschopp J. A role for mitochondria in NLRP3 inflammasome activation. Nature. 2011;469(7329):221-225. [PubMed: 21124315]

41. Navar LG. The intrarenal renin-angiotensin system in hypertension. Kidney Int. 2004;65(4):15221532. [PubMed: 15086502]

42. Navar LG, Harrison-Bernard LM, Nishiyama A, Kobori H. Regulation of intrarenal angiotensin II in hypertension. Hypertension. 2002;39(2 Pt 2):316-322. [PubMed: 11882566]

43. Vaziri ND, Liang K, Ding Y. Increased nitric oxide inactivation by reactive oxygen species in leadinduced hypertension. Kidney Int. 1999;56(4):1492-1498. [PubMed: 10504500] 
44. Vaziri ND, Lin CY, Farmand F, Sindhu RK. Superoxide dismutase, catalase, glutathione peroxidase and NADPH oxidase in lead-induced hypertension. Kidney Int. 2003;63(1):186-194. [PubMed: 12472782]

45. Vendrov AE, Hakim ZS, Madamanchi NR, Rojas M, Madamanchi C, Runge MS. Atherosclerosis is attenuated by limiting superoxide generation in both macrophages and vessel wall cells. Arterioscler Thromb Vasc Biol. 2007;27(12):2714-2721. [PubMed: 17823367]

46. Chen S, Ge Y, Si J, Rifai A, Dworkin LD, Gong R. Candesartan suppresses chronic renal inflammation by a novel antioxidant action independent of AT1R blockade. Kidney Int. 2008;74(9):1128-1138. [PubMed: 18650791]

47. Anavekar NS, Solomon SD. Angiotensin II receptor blockade and ventricular remodelling. Journal of the renin-angiotensin-aldosterone system : JRAAS. 2005;6(1):43-48. [PubMed: 16088851]

48. Okamura A, Rakugi H, Ohishi M, et al. Upregulation of renin-angiotensin system during differentiation of monocytes to macrophages. J Hypertens. 1999;17(4):537-545. [PubMed: 10404956]

49. Dhande I, Ali Q, Hussain T. Proximal tubule angiotensin AT2 receptors mediate an antiinflammatory response via interleukin-10: role in renoprotection in obese rats. Hypertension. 2013;61(6):1218-1226. [PubMed: 23547236]

50. Dhande I, Ma W, Hussain T. Angiotensin AT2 receptor stimulation is anti-inflammatory in lipopolysaccharide-activated THP-1 macrophages via increased interleukin-10 production. Hypertens Res. 2015;38(1):21-29. [PubMed: 25209104]

51. Garcia GE. ANG II receptor antagonists as modulators of macrophages polarization. Am J Physiol Renal Physiol. 2010;298(4):F868-869. [PubMed: 20130123]

52. Saraiva M, O'Garra A. The regulation of IL-10 production by immune cells. Nat Rev Immunol. 2010;10(3):170-181. [PubMed: 20154735]

53. Zhang P, Martin M, Michalek SM, Katz J. Role of mitogen-activated protein kinases and NFkappaB in the regulation of proinflammatory and anti-inflammatory cytokines by Porphyromonas gingivalis hemagglutinin B. Infection and immunity. 2005;73(7):3990-3998. [PubMed: 15972486]

54. Hahn AW, Jonas U, Buhler FR, Resink TJ. Activation of human peripheral monocytes by angiotensin II. FEBS Lett. 1994;347(2-3):178-180. [PubMed: 7518396]

55. Kranzhofer R, Browatzki M, Schmidt J, Kubler W. Angiotensin II activates the proinflammatory transcription factor nuclear factor-kappaB in human monocytes. Biochem Biophys Res Commun. 1999;257(3):826-828. [PubMed: 10208867]

56. Ma LJ, Corsa BA, Zhou J, et al. Angiotensin type 1 receptor modulates macrophage polarization and renal injury in obesity. Am J Physiol Renal Physiol. 2011;300(5):F1203-1213. [PubMed: 21367915]

57. Kim S, Zingler M, Harrison JK, et al. Angiotensin II Regulation of Proliferation, Differentiation, and Engraftment of Hematopoietic Stem Cells. Hypertension. 2016;67(3):574-584. [PubMed: 26781279]

58. Crowley SD, Song YS, Sprung G, et al. A role for angiotensin II type 1 receptors on bone marrowderived cells in the pathogenesis of angiotensin II-dependent hypertension. Hypertension. 2010;55(1):99-108. [PubMed: 19996062]

59. Kato H, Ishida J, Nagano K, et al. Deterioration of atherosclerosis in mice lacking angiotensin II type 1A receptor in bone marrow-derived cells. Lab Invest. 2008;88(7):731-739. [PubMed: 18490898]

60. Fukuda D, Sata M, Ishizaka N, Nagai R. Critical role of bone marrow angiotensin II type 1 receptor in the pathogenesis of atherosclerosis in apolipoprotein $\mathrm{E}$ deficient mice. Arterioscler Thromb Vasc Biol. 2008;28(1):90-96. [PubMed: 17962627]

61. Zhang JD, Patel MB, Song YS, et al. A novel role for type 1 angiotensin receptors on T lymphocytes to limit target organ damage in hypertension. Circ Res. 2012;110(12):1604-1617. [PubMed: 22534490]

62. Zhang JD, Patel MB, Griffiths R, et al. Type 1 angiotensin receptors on macrophages ameliorate IL-1 receptor-mediated kidney fibrosis. J Clin Invest. 2014;124(5):2198-2203. [PubMed: 24743144] 
63. Usher MG, Duan SZ, Ivaschenko CY, et al. Myeloid mineralocorticoid receptor controls macrophage polarization and cardiovascular hypertrophy and remodeling in mice. J Clin Invest. 2010;120(9):3350-3364. [PubMed: 20697155]

64. Shen XZ, Li P, Weiss D, et al. Mice with enhanced macrophage angiotensin-converting enzyme are resistant to melanoma. Am J Pathol. 2007;170(6):2122-2134. [PubMed: 17525278]

65. Bernstein KE, Khan Z, Giani JF, Cao DY, Bernstein EA, Shen XZ. Angiotensinconverting enzyme in innate and adaptive immunity. Nat Rev Nephrol. 2018;14(5):325-336. [PubMed: 29578208]

66. Gonzalez-Villalobos RA, Janjoulia T, Fletcher NK, et al. The absence of intrarenal ACE protects against hypertension. J Clin Invest. 2013;123(5):2011-2023. [PubMed: 23619363]

67. Rosales C Neutrophil: A Cell with Many Roles in Inflammation or Several Cell Types? Front Physiol. 2018;9:113. [PubMed: 29515456]

68. Nicholls SJ, Hazen SL. Myeloperoxidase and cardiovascular disease. Arterioscler Thromb Vasc Biol. 2005;25(6):1102-1111. [PubMed: 15790935]

69. Zhang C, Reiter C, Eiserich JP, et al. L-arginine chlorination products inhibit endothelial nitric oxide production. J Biol Chem. 2001;276(29):27159-27165. [PubMed: 11375389]

70. Marsche G, Heller R, Fauler G, et al. 2-chlorohexadecanal derived from hypochlorite-modified high-density lipoprotein-associated plasmalogen is a natural inhibitor of endothelial nitric oxide biosynthesis. Arterioscler Thromb Vasc Biol. 2004;24(12):2302-2306. [PubMed: 15514213]

71. Auchere F, Capeillere-Blandin C. NADPH as a co-substrate for studies of the chlorinating activity of myeloperoxidase. Biochem J. 1999;343 Pt 3:603-613. [PubMed: 10527939]

72. Eiserich JP, Baldus S, Brennan ML, et al. Myeloperoxidase, a leukocyte-derived vascular NO oxidase. Science. 2002;296(5577):2391-2394. [PubMed: 12089442]

73. Rudolph TK, Wipper S, Reiter B, et al. Myeloperoxidase deficiency preserves vasomotor function in humans. Eur Heart J. 2012;33(13):1625-1634. [PubMed: 21724624]

74. Collin M, Bigley V. Human dendritic cell subsets: an update. Immunology. 2018;154(1):3-20. [PubMed: 29313948]

75. Hevia D, Araos P, Prado C, et al. Myeloid CD11c(+) Antigen-Presenting Cells Ablation Prevents Hypertension in Response to Angiotensin II Plus High-Salt Diet. Hypertension. 2018;71(4):709718. [PubMed: 29378857]

76. Lu X, Rudemiller NP, Privratsky JR, et al. Classical Dendritic Cells Mediate Hypertension by Promoting Renal Oxidative Stress and Fluid Retention. Hypertension. 2020;75(1):131-138. [PubMed: 31786985]

77. Nahmod K, Gentilini C, Vermeulen M, et al. Impaired function of dendritic cells deficient in angiotensin II type 1 receptors. J Pharmacol Exp Ther. 2010;334(3):854-862. [PubMed: 20516139]

78. Vinh A, Chen W, Blinder Y, et al. Inhibition and genetic ablation of the B7/CD28 T-cell costimulation axis prevents experimental hypertension. Circulation. 2010;122(24):2529-2537. [PubMed: 21126972]

79. Itani HA, Xiao L, Saleh MA, et al. CD70 Exacerbates Blood Pressure Elevation and Renal Damage in Response to Repeated Hypertensive Stimuli. Circ Res. 2016;118(8):1233-1243. [PubMed: 26988069]

80. Herrada AA, Contreras FJ, Marini NP, et al. Aldosterone promotes autoimmune damage by enhancing Th17-mediated immunity. J Immunol. 2010;184(1):191-202. [PubMed: 19949098]

81. Lu X, Rudemiller NP, Wen Y, et al. A20 in Myeloid Cells Protects Against Hypertension by Inhibiting Dendritic Cell-Mediated T-Cell Activation. Circ Res. 2019;125(12):1055-1066. [PubMed: 31630621]

82. Kirabo A, Fontana V, de Faria AP, et al. DC isoketal-modified proteins activate $\mathrm{T}$ cells and promote hypertension. J Clin Invest. 2014;124(10):4642-4656. [PubMed: 25244096]

83. Barbaro NR, Foss JD, Kryshtal DO, et al. Dendritic Cell Amiloride-Sensitive Channels Mediate Sodium-Induced Inflammation and Hypertension. Cell reports. 2017;21(4):1009-1020. [PubMed: 29069584]

84. Tsay GJ, Zouali M. The Interplay Between Innate-Like B Cells and Other Cell Types in Autoimmunity. Front Immunol. 2018;9:1064. [PubMed: 29868023] 
85. Expression Kabelitz D. and function of Toll-like receptors in T lymphocytes. Curr Opin Immunol. 2007;19(1):39-45. [PubMed: 17129718]

86. Horan MJ, Lovenberg W. Genetic rat models for hypertension: guidelines for breeding, care and use. Journal of hypertension Supplement : official journal of the International Society of Hypertension. 1986;4(3):S7-9.

87. Svendsen UG. Spontaneous hypertension and hypertensive vascular disease in the NZB strain of mice. Acta Pathol Microbiol Scand A. 1977;85(4):548-554. [PubMed: 899791]

88. Svendsen UG. The importance of thymus in the pathogenesis of the chronic phase of hypertension in mice following partial infarction of the kidney. Acta Pathol Microbiol Scand A. 1977;85(4):539-547. [PubMed: 331861]

89. Norman RA Jr., Galloway PG, Dzielak DJ, Huang M. Mechanisms of partial renal infarct hypertension. J Hypertens. 1988;6(5):397-403. [PubMed: 3385205]

90. Okuda T, Grollman A. Passive transfer of autoimmune induced hypertension in the rat by lymph node cells. Tex Rep Biol Med. 1967;25(2):257-264. [PubMed: 6040652]

91. Guzik TJ, Hoch NE, Brown KA, et al. Role of the T cell in the genesis of angiotensin II induced hypertension and vascular dysfunction. J Exp Med. 2007;204(10):2449-2460. [PubMed: 17875676]

92. Trott DW, Thabet SR, Kirabo A, et al. Oligoclonal CD8+ T cells play a critical role in the development of hypertension. Hypertension. 2014;64(5):1108-1115. [PubMed: 25259750]

93. Mattson DL, Lund H, Guo C, Rudemiller N, Geurts AM, Jacob H. Genetic mutation of recombination activating gene 1 in Dahl salt-sensitive rats attenuates hypertension and renal damage. Am J Physiol Regul Integr Comp Physiol. 2013;304(6):R407-414. [PubMed: 23364523]

94. Crowley SD, Song YS, Lin EE, Griffiths R, Kim HS, Ruiz P. Lymphocyte responses exacerbate angiotensin II-dependent hypertension. Am J Physiol Regul Integr Comp Physiol. 2010;298(4):R1089-1097. [PubMed: 20147609]

95. Rudemiller N, Lund H, Jacob HJ, Geurts AM, Mattson DL, PhysGen Knockout P. CD247 modulates blood pressure by altering T-lymphocyte infiltration in the kidney. Hypertension. 2014;63(3):559-564. [PubMed: 24343121]

96. Ji H, Pai AV, West CA, Wu X, Speth RC, Sandberg K. Loss of Resistance to Angiotensin IIInduced Hypertension in the Jackson Laboratory Recombination-Activating Gene Null Mouse on the C57BL/6J Background. Hypertension. 2017;69(6):1121-1127. [PubMed: 28438904]

97. Dobbs K, Tabellini G, Calzoni E, et al. Natural Killer Cells from Patients with RecombinaseActivating Gene and Non-Homologous End Joining Gene Defects Comprise a Higher Frequency of CD56(bright) NKG2A(+++) Cells, and Yet Display Increased Degranulation and Higher Perforin Content. Front Immunol. 2017;8:798. [PubMed: 28769923]

98. Karo JM, Schatz DG, Sun JC. The RAG recombinase dictates functional heterogeneity and cellular fitness in natural killer cells. Cell. 2014;159(1):94-107. [PubMed: 25259923]

99. Fraser R, Whitley GS, Thilaganathan B, Cartwright JE. Decidual natural killer cells regulate vessel stability: implications for impaired spiral artery remodelling. J Reprod Immunol. 2015;110:54-60. [PubMed: 26004035]

100. Taylor EB, Sasser JM. Natural killer cells and T lymphocytes in pregnancy and pre-eclampsia. Clin Sci (Lond). 2017;131(24):2911-2917. [PubMed: 29222389]

101. De Miguel C, Guo C, Lund H, Feng D, Mattson DL. Infiltrating T lymphocytes in the kidney increase oxidative stress and participate in the development of hypertension and renal disease. Am J Physiol Renal Physiol. 2011;300(3):F734-742. [PubMed: 21159736]

102. Huang B, Cheng Y, Usa K, et al. Renal Tumor Necrosis Factor alpha Contributes to Hypertension in Dahl Salt-Sensitive Rats. Sci Rep. 2016;6:21960. [PubMed: 26916681]

103. Tran LT, MacLeod KM, McNeill JH. Chronic etanercept treatment prevents the development of hypertension in fructose-fed rats. Molecular and cellular biochemistry. 2009;330(1-2):219-228. [PubMed: 19440659]

104. Sriramula S, Haque M, Majid DS, Francis J. Involvement of tumor necrosis factor-alpha in angiotensin II-mediated effects on salt appetite, hypertension, and cardiac hypertrophy. Hypertension. 2008;51(5):1345-1351. [PubMed: 18391105] 
105. Kamat NV, Thabet SR, Xiao L, et al. Renal transporter activation during angiotensin-II hypertension is blunted in interferon-gamma-/- and interleukin-17A-/- mice. Hypertension. 2015;65(3):569-576. [PubMed: 25601932]

106. Madhur MS, Lob HE, McCann LA, et al. Interleukin 17 promotes angiotensin II-induced hypertension and vascular dysfunction. Hypertension. 2010;55(2):500-507. [PubMed: 20038749]

107. Krebs CF, Lange S, Niemann G, et al. Deficiency of the interleukin 17/23 axis accelerates renal injury in mice with deoxycorticosterone acetate+angiotensin ii-induced hypertension. Hypertension. 2014;63(3):565-571. [PubMed: 24366079]

108. Tanase DM, Gosav EM, Radu S, et al. Arterial Hypertension and Interleukins: Potential Therapeutic Target or Future Diagnostic Marker? International journal of hypertension. 2019;2019:3159283. [PubMed: 31186952]

109. Akbari H, Asadikaram G, Jafari A, et al. Atorvastatin, losartan and captopril may upregulate IL-22 in hypertension and coronary artery disease; the role of gene polymorphism. Life Sci. 2018;207:525-531. [PubMed: 29981321]

110. Ye J, Ji Q, Liu J, et al. Interleukin 22 Promotes Blood Pressure Elevation and Endothelial Dysfunction in Angiotensin II-Treated Mice. J Am Heart Assoc. 2017;6(10).

111. Akdis CA, Akdis M. Mechanisms and treatment of allergic disease in the big picture of regulatory T cells. J Allergy Clin Immunol. 2009;123(4):735-746; quiz 747-738. [PubMed: 19348912]

112. Barhoumi T, Kasal DA, Li MW, et al. T regulatory lymphocytes prevent angiotensin II-induced hypertension and vascular injury. Hypertension. 2011;57(3):469-476. [PubMed: 21263125]

113. Matrougui K, Abd Elmageed Z, Kassan M, et al. Natural regulatory T cells control coronary arteriolar endothelial dysfunction in hypertensive mice. Am J Pathol. 2011;178(1):434-441. [PubMed: 21224080]

114. Kasal DA, Barhoumi T, Li MW, et al. T regulatory lymphocytes prevent aldosterone-induced vascular injury. Hypertension. 2012;59(2):324-330. [PubMed: 22146512]

115. Mian MO, Barhoumi T, Briet M, Paradis P, Schiffrin EL. Deficiency of T-regulatory cells exaggerates angiotensin II-induced microvascular injury by enhancing immune responses. $\mathrm{J}$ Hypertens. 2016;34(1):97-108. [PubMed: 26630215]

116. Viel EC, Lemarie CA, Benkirane K, Paradis P, Schiffrin EL. Immune regulation and vascular inflammation in genetic hypertension. Am J Physiol Heart Circ Physiol. 2010;298(3):H938-944. [PubMed: 20044442]

117. Suryaprabha P, Padma T, Rao UB. Increased serum IgG levels in essential hypertension. Immunol Lett. 1984;8(3):143-145. [PubMed: 6500633]

118. Hilme E, Herlitz H, Soderstrom T, Hansson L. Increased secretion of immunoglobulins in malignant hypertension. J Hypertens. 1989;7(2):91-95. [PubMed: 2647845]

119. Chan CT, Sobey CG, Lieu M, et al. Obligatory Role for B Cells in the Development of Angiotensin II-Dependent Hypertension. Hypertension. 2015;66(5):1023-1033. [PubMed: 26351030]

120. Taylor EB, Barati MT, Powell DW, Turbeville HR, Ryan MJ. Plasma Cell Depletion Attenuates Hypertension in an Experimental Model of Autoimmune Disease. Hypertension. 2018;71(4):719-728. [PubMed: 29378858]

121. Takeda K, Akira S. Toll-like receptors in innate immunity. Int Immunol. 2005;17(1):1-14. [PubMed: 15585605]

122. Kawasaki T, Kawai T. Toll-like receptor signaling pathways. Front Immunol. 2014;5:461. [PubMed: 25309543]

123. Harwani SC, Chapleau MW, Legge KL, Ballas ZK, Abboud FM. Neurohormonal modulation of the innate immune system is proinflammatory in the prehypertensive spontaneously hypertensive rat, a genetic model of essential hypertension. Circ Res. 2012;111(9):1190-1197. [PubMed: 22904093]

124. Marketou ME, Kontaraki JE, Zacharis EA, et al. TLR2 and TLR4 gene expression in peripheral monocytes in nondiabetic hypertensive patients: the effect of intensive blood pressure-lowering. Journal of clinical hypertension. 2012;14(5):330-335. [PubMed: 22533660] 
125. Bomfim GF, Dos Santos RA, Oliveira MA, et al. Toll-like receptor 4 contributes to blood pressure regulation and vascular contraction in spontaneously hypertensive rats. Clin Sci (Lond). 2012;122(11):535-543. [PubMed: 22233532]

126. Nunes KP, Bomfim GF, Toque HA, Szasz T, Clinton Webb R. Toll-like receptor 4 (TLR4) impairs nitric oxide contributing to Angiotensin II-induced cavernosal dysfunction. Life Sci. 2017;191:219-226. [PubMed: 29032115]

127. Nunes KP, de Oliveira AA, Lima VV, Webb RC. Toll-Like Receptor 4 and Blood Pressure: Lessons From Animal Studies. Front Physiol. 2019;10:655. [PubMed: 31191352]

128. Dange RB, Agarwal D, Masson GS, et al. Central blockade of TLR4 improves cardiac function and attenuates myocardial inflammation in angiotensin II-induced hypertension. Cardiovasc Res. 2014;103(1):17-27. [PubMed: 24667851]

129. Dange RB, Peng H, Feng Y, Francis J. Mice lacking the gene for Toll Like receptor-4 (TLR4) had an attenuated blood pressure response to Angiotensin II infusion. FASEB. 2013;27(Supplement 1).

130. Singh MV, Cicha MZ, Meyerholz DK, Chapleau MW, Abboud FM. Dual Activation of TRIF and MyD88 Adaptor Proteins by Angiotensin II Evokes Opposing Effects on Pressure, Cardiac Hypertrophy, and Inflammatory Gene Expression. Hypertension. 2015;66(3):647-656. [PubMed: 26195481]

131. Sollinger D, Eissler R, Lorenz S, et al. Damage-associated molecular pattern activated Toll-like receptor 4 signalling modulates blood pressure in L-NAME-induced hypertension. Cardiovasc Res. 2014;101(3):464-472. [PubMed: 24302630]

132. Krishnan SM, Dowling JK, Ling YH, et al. Inflammasome activity is essential for one kidney/ deoxycorticosterone acetate/salt-induced hypertension in mice. Br J Pharmacol. 2016;173(4):752-765. [PubMed: 26103560]

133. Krishnan SM, Ling YH, Huuskes BM, et al. Pharmacological inhibition of the NLRP3 inflammasome reduces blood pressure, renal damage, and dysfunction in salt-sensitive hypertension. Cardiovasc Res. 2019;115(4):776-787. [PubMed: 30357309]

134. Marchetti C, Swartzwelter B, Gamboni F, et al. OLT1177, a beta-sulfonyl nitrile compound, safe in humans, inhibits the NLRP3 inflammasome and reverses the metabolic cost of inflammation. Proc Natl Acad Sci U S A. 2018;115(7):E1530-E1539. [PubMed: 29378952]

135. Hagita S, Osaka M, Shimokado K, Yoshida M. Adipose inflammation initiates recruitment of leukocytes to mouse femoral artery: role of adipo-vascular axis in chronic inflammation. PLoS One. 2011;6(5):e19871. [PubMed: 21625491]

136. Kossmann $\mathrm{S}, \mathrm{Hu} \mathrm{H}$, Steven $\mathrm{S}$, et al. Inflammatory monocytes determine endothelial nitric-oxide synthase uncoupling and nitro-oxidative stress induced by angiotensin II. J Biol Chem. 2014;289(40):27540-27550. [PubMed: 25143378]

137. Ohman MK, Luo W, Wang H, et al. Perivascular visceral adipose tissue induces atherosclerosis in apolipoprotein E deficient mice. Atherosclerosis. 2011;219(1):33-39. [PubMed: 21835408]

138. Vaziri ND, Rodriguez-Iturbe B. Mechanisms of disease: oxidative stress and inflammation in the pathogenesis of hypertension. Nat Clin Pract Nephrol. 2006;2(10):582-593. [PubMed: 17003837]

139. Liu J, Yang F, Yang XP, Jankowski M, Pagano PJ. NAD(P)H oxidase mediates angiotensin IIinduced vascular macrophage infiltration and medial hypertrophy. Arterioscler Thromb Vasc Biol. 2003;23(5):776-782. [PubMed: 12637340]

140. Bu DX, Lichtman AH. T cells and blood vessels: costimulation turns up the pressure. Circulation. 2010;122(24):2495-2498. [PubMed: 21126974]

141. Harrison DG, Vinh A, Lob H, Madhur MS. Role of the adaptive immune system in hypertension. Curr Opin Pharmacol. 2010;10(2):203-207. [PubMed: 20167535]

142. Schiffrin EL. T lymphocytes: a role in hypertension? Curr Opin Nephrol Hypertens. 2010;19(2):181-186. [PubMed: 20040866]

143. Lima VV, Zemse SM, Chiao CW, et al. Interleukin-10 limits increased blood pressure and vascular RhoA/Rho-kinase signaling in angiotensin II-infused mice. Life Sci. 2016;145:137-143. [PubMed: 26682936] 
144. Ryan MJ. An update on immune system activation in the pathogenesis of hypertension. Hypertension. 2013;62(2):226-230. [PubMed: 23734005]

145. Rodriguez-Iturbe B, Quiroz Y, Ferrebuz A, Parra G, Vaziri ND. Evolution of renal interstitial inflammation and NF-kappaB activation in spontaneously hypertensive rats. Am J Nephrol. 2004;24(6):587-594. [PubMed: 15564764]

146. Crosswhite P, Sun Z. Ribonucleic acid interference knockdown of interleukin 6 attenuates coldinduced hypertension. Hypertension. 2010;55(6):1484-1491. [PubMed: 20385973]

147. Franco M, Tapia E, Bautista R, et al. Impaired pressure natriuresis resulting in salt-sensitive hypertension is caused by tubulointerstitial immune cell infiltration in the kidney. Am J Physiol Renal Physiol. 2013;304(7):F982-990. [PubMed: 23364804]

148. Gratze P, Dechend R, Stocker C, et al. Novel role for inhibitor of differentiation 2 in the genesis of angiotensin II-induced hypertension. Circulation. 2008;117(20):2645-2656. [PubMed: 18474814]

149. Nguyen H, Chiasson VL, Chatterjee P, Kopriva SE, Young KJ, Mitchell BM. Interleukin-17 causes Rho-kinase-mediated endothelial dysfunction and hypertension. Cardiovasc Res. 2013;97(4):696-704. [PubMed: 23263331]

150. Norlander AE, Saleh MA, Kamat NV, et al. Interleukin-17A Regulates Renal Sodium Transporters and Renal Injury in Angiotensin II-Induced Hypertension. Hypertension. 2016;68(1):167-174. [PubMed: 27141060]

151. Sun XN, Li C, Liu Y, et al. T-Cell Mineralocorticoid Receptor Controls Blood Pressure by Regulating Interferon-Gamma. Circ Res. 2017;120(10):1584-1597. [PubMed: 28298295]

152. Rucker AJ, Rudemiller NP, Crowley SD. Salt, Hypertension, and Immunity. Annual review of physiology. 2018;80:283-307.

153. Tian N, Gu JW, Jordan S, Rose RA, Hughson MD, Manning RD, Jr. Immune suppression prevents renal damage and dysfunction and reduces arterial pressure in salt-sensitive hypertension. Am J Physiol Heart Circ Physiol. 2007;292(2):H1018-1025. [PubMed: 17040973]

154. McMaster WG, Kirabo A, Madhur MS, Harrison DG. Inflammation, immunity, and hypertensive end-organ damage. Circ Res. 2015;116(6):1022-1033. [PubMed: 25767287]

155. Xia Y, Jin X, Yan J, Entman ML, Wang Y. CXCR6 plays a critical role in angiotensin II-induced renal injury and fibrosis. Arterioscler Thromb Vasc Biol. 2014;34(7):1422-1428. [PubMed: 24855055]

156. Thang LV, Demel SL, Crawford R, et al. Macrophage depletion lowers blood pressure and restores sympathetic nerve alpha2-adrenergic receptor function in mesenteric arteries of DOCAsalt hypertensive rats. Am J Physiol Heart Circ Physiol. 2015;309(7):H1186-1197. [PubMed: 26320034]

157. Kain D, Amit U, Yagil C, et al. Macrophages dictate the progression and manifestation of hypertensive heart disease. Int J Cardiol. 2016;203:381-395. [PubMed: 26539962]

158. Wenzel U, Turner JE, Krebs C, Kurts C, Harrison DG, Ehmke H. Immune Mechanisms in Arterial Hypertension. J Am Soc Nephrol. 2016;27(3):677-686. [PubMed: 26319245]

159. Kitamoto K, Machida Y, Uchida J, et al. Effects of liposome clodronate on renal leukocyte populations and renal fibrosis in murine obstructive nephropathy. J Pharmacol Sci. 2009;111(3):285-292. [PubMed: 19893275]

160. Makino A, Skelton MM, Zou AP, Roman RJ, Cowley AW, Jr. Increased renal medullary oxidative stress produces hypertension. Hypertension. 2002;39(2 Pt 2):667-672. [PubMed: 11882628]

161. Cowley AW Jr. Renal medullary oxidative stress, pressure-natriuresis, and hypertension. Hypertension. 2008;52(5):777-786. [PubMed: 18852392]

162. Herz J, Filiano AJ, Smith A, Yogev N, Kipnis J. Myeloid Cells in the Central Nervous System. Immunity. 2017;46(6):943-956. [PubMed: 28636961]

163. Shen XZ, Li Y, Li L, et al. Microglia participate in neurogenic regulation of hypertension. Hypertension. 2015;66(2):309-316. [PubMed: 26056339]

164. Liu Y, Jacobowitz DM, Barone F, et al. Quantitation of perivascular monocytes and macrophages around cerebral blood vessels of hypertensive and aged rats. J Cereb Blood Flow Metab. 1994;14(2):348-352. [PubMed: 8113330] 
165. Iyonaga T, Shinohara K, Mastuura T, Hirooka Y, Tsutsui H. Brain perivascular macrophages contribute to the development of hypertension in stroke-prone spontaneously hypertensive rats via sympathetic activation. Hypertens Res. 2019.

166. Zubcevic J, Waki H, Raizada MK, Paton JF. Autonomic-immune-vascular interaction: an emerging concept for neurogenic hypertension. Hypertension. 2011;57(6):1026-1033. [PubMed: 21536990]

167. Shi P, Diez-Freire C, Jun JY, et al. Brain microglial cytokines in neurogenic hypertension. Hypertension. 2010;56(2):297-303. [PubMed: 20547972]

168. Kang YM, Ma Y, Zheng JP, et al. Brain nuclear factor-kappa B activation contributes to neurohumoral excitation in angiotensin II-induced hypertension. Cardiovasc Res. 2009;82(3):503-512. [PubMed: 19246475]

169. Kang YM, He RL, Yang LM, et al. Brain tumour necrosis factor-alpha modulates neurotransmitters in hypothalamic paraventricular nucleus in heart failure. Cardiovasc Res. 2009;83(4):737-746. [PubMed: 19457890]

170. Ando H, Zhou J, Macova M, Imboden H, Saavedra JM. Angiotensin II AT1 receptor blockade reverses pathological hypertrophy and inflammation in brain microvessels of spontaneously hypertensive rats. Stroke. 2004;35(7):1726-1731. [PubMed: 15143297]

171. Scanzano A, Cosentino M. Adrenergic regulation of innate immunity: a review. Front Pharmacol. 2015;6:171. [PubMed: 26321956]

172. Li DJ, Evans RG, Yang ZW, et al. Dysfunction of the cholinergic anti-inflammatory pathway mediates organ damage in hypertension. Hypertension. 2011;57(2):298-307. [PubMed: 21173343]

173. Baez-Pagan CA, Delgado-Velez M, Lasalde-Dominicci JA. Activation of the Macrophage alpha7 Nicotinic Acetylcholine Receptor and Control of Inflammation. J Neuroimmune Pharmacol. 2015;10(3):468-476. [PubMed: 25870122] 
M1 Macrophages Stimulated by

IFN $\gamma$, TNF $\alpha$, LPS, Ang II

ROS, Aldosterone

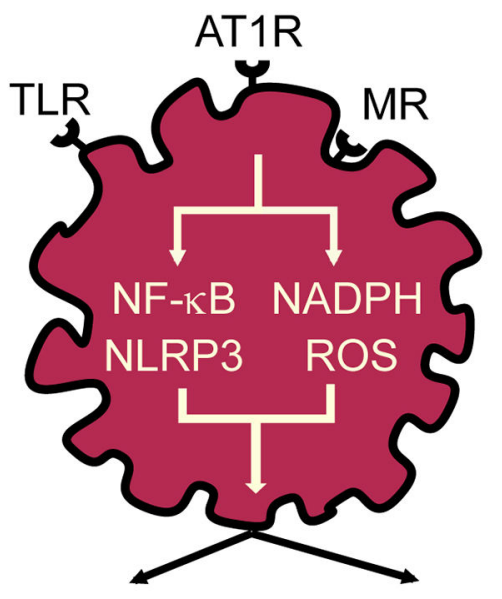

Chemokines

-MCP-1/CCR2

-MCP-2/CCL8
Cytokines

- TNF $\alpha$,

- IL-1 $\beta$, IL-6,

IL-12, IL-15,

IL-17, IL-22
M2 Macrophages

Stimulated by

IL-4, IL-13, IL-10, Glucocorticoids, C21 compund, IgG

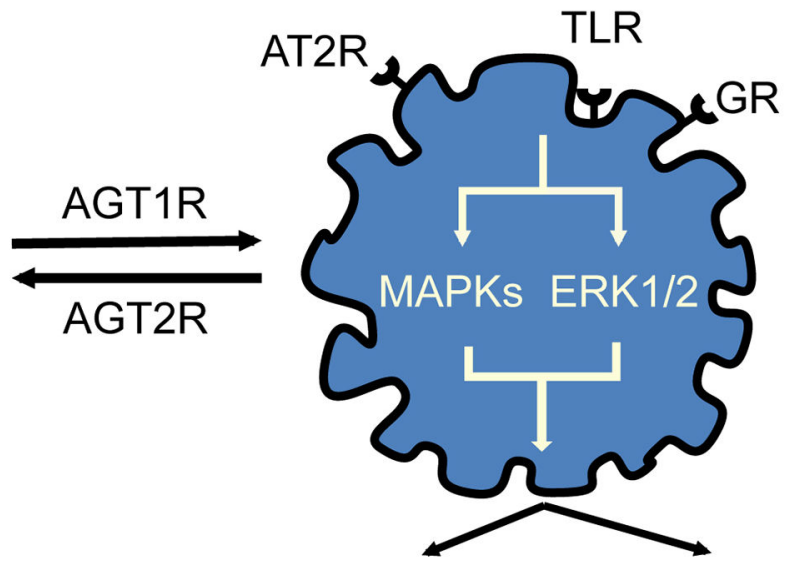

Cytokines

- IL-10

Marix

- TGF- $\beta$

Figure 1. Effects of Angiotensin II on Macrophage Polarization.

Angiotensin (Ang) II activates AT1R to generate a pro-inflammatory M1 macrophage phenotype. Ang II enhances TLR4 signaling and promotes M1 release of ROS, cytokines, and chemokines, causing more inflammation. Conversely, activation of AT2R promotes M2 differentiation, anti-inflammatory IL10 release, and tissue repair. 


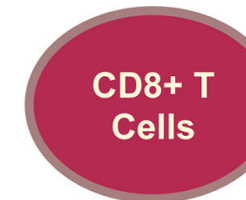

NAPDH

Oxidase/ROS
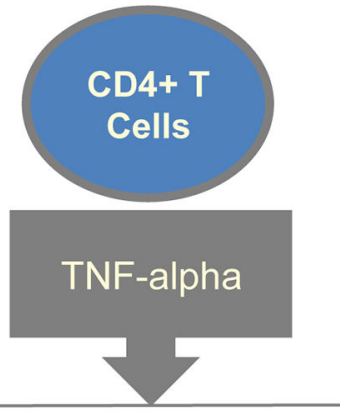

\section{Endothelial}

Dysfunction

\section{Sodium Retention}
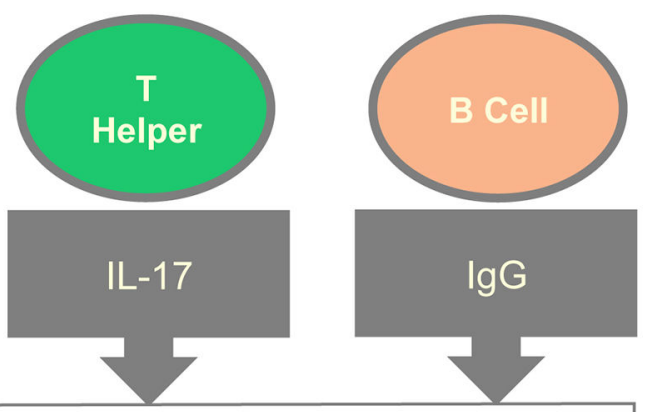

Innate Immune

System Activation and Infiltration

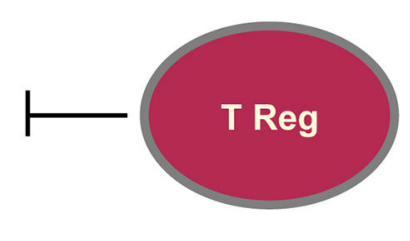

\section{Hypertension}

Figure 2. Role of the Adaptive Immune System in Hypertension.

$\mathrm{CD} 8+, \mathrm{CD} 4+, \mathrm{T}$ helper cells, and B lymphocytes drive hypertension through mediators such as NADPH oxidase, production of ROS, cytokines (TNF-alpha and IL-17), and IgG production. These mediators worsen hypertension through endothelial dysfunction, sodium retention and impaired natriuresis in the kidney, as well as through further immune activation, including induction of M2 macrophage differentiation. T regulatory cells have a crucial role in modulating and decreasing the adaptive immune system response and help reduce hypertension. 


\section{Ang II, aldosterone, cytokines, shear stress}

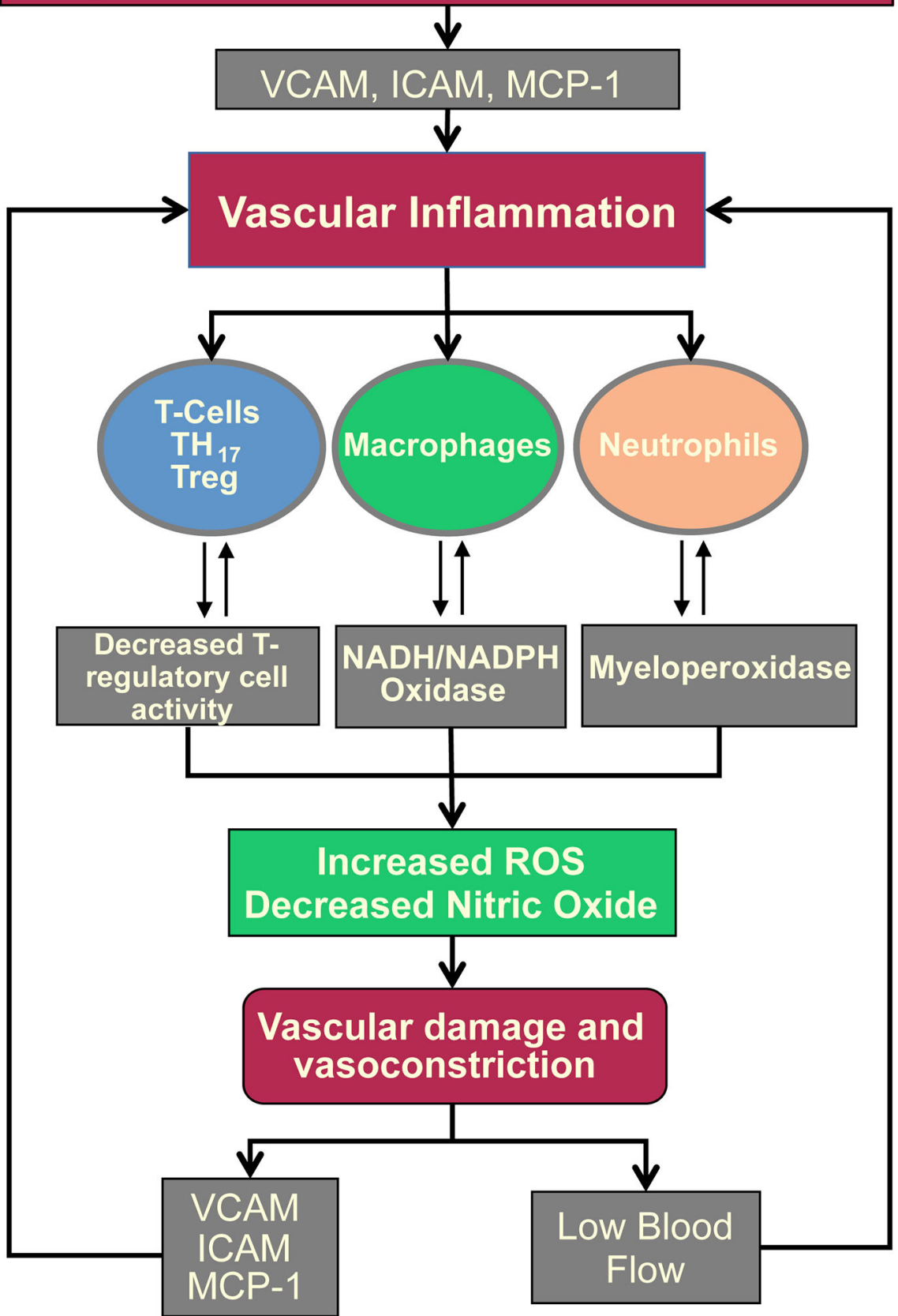

Figure 3. Vascular Inflammation.

Ang II, aldosterone, cytokines, and shear stress all stimulate adhesion factors to promote immune cell recruitment. Activation of immune cell myeloperoxidases and NADPH oxidases increase vascular ROS, metalloproteinases, tumor TGF- $\beta$, and pro-inflammatory endothelial cytokines and chemokines. These all promote endothelial dysfunction, arterial stiffness, decreased vascular flow, and perpetuate the cycle of inflammation and RAS activation. 


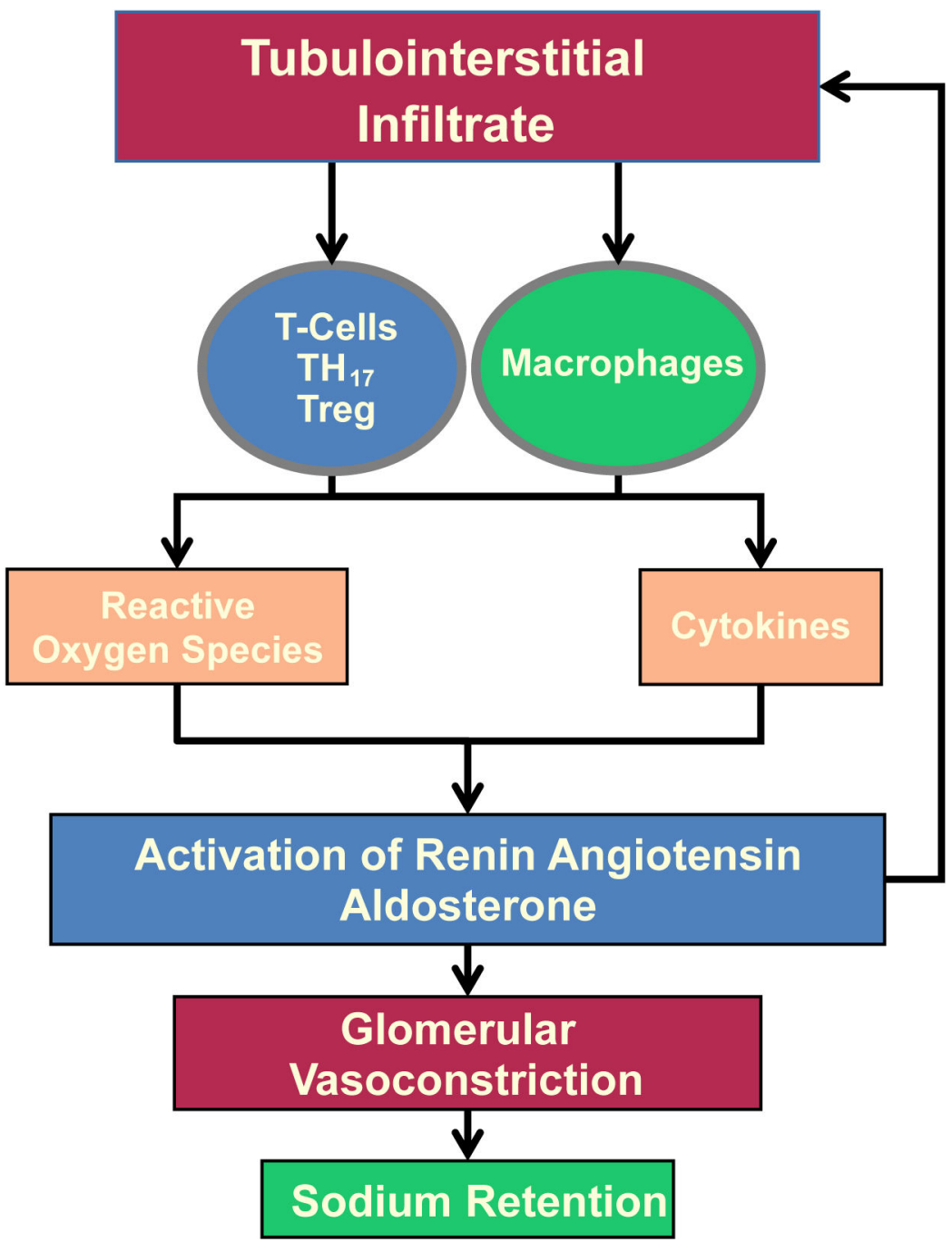

Figure 4. Immunity and Renal Responses.

Lymphocytes and macrophages promote oxidative stress and intrarenal Ang II generation inducing leukocyte infiltration, tissue damage, and excessive proximal tubular sodium reabsorption. 


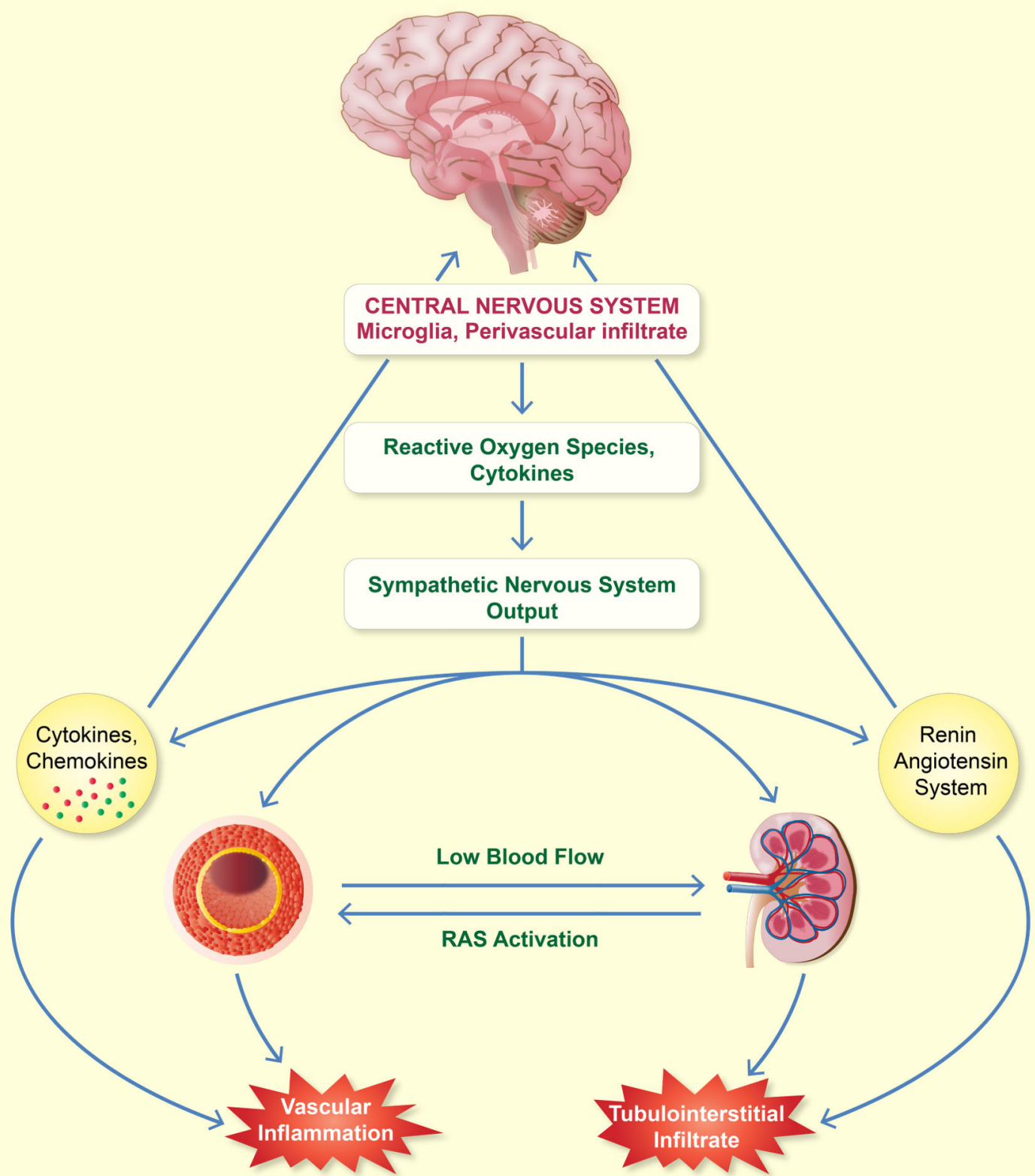

Figure 5. Contribution of Central Nervous System to Hypertension.

Activation of microglia and perivascular macrophages by increased systemic Ang II or cytokines promotes ROS and local cytokines, activating the sympathetic nervous system. SNS activation increases vascular and renal inflammation, causing hypertension. 